\title{
A SERIEDADE DE LUIS ALBERTO WARAT
}

THE SERIOUSNESS OF LUIS ALBERTO WARAT

LA SERIEDAD DE LUIS ALBERTO WARAT

Cesar Luiz Pasold ${ }^{1}$

1 Doutor em Direito do Estado pela Universidade de São Paulo; Pós-Doutor em Direito das Relações Sociais pela Universidade Federal do Paraná; Mestre em Instituições Políticas e Jurídicas pela Universidade Federal de Santa Catarina; Advogado ( OAB/SC 943) e Professor no Programa de Doutorado em Ciência Jurídica da UNIVALI. 


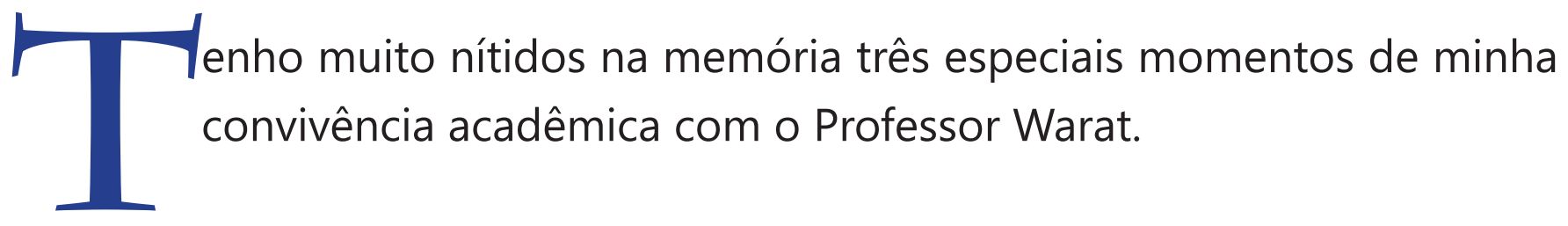

O primeiro deles, em 1979, quando eu estava finalizando os créditos no Mestrado em Direito da UFSC, e fomos todos convidados pelo Prof. Dr. Paulo Blasi para assistir à Palestra, de um "professor argentino", sobre Filosofia, Comunicação e Direito.

Fui e assisti a um extraordinário comunicador, interagindo eficazmente com seu auditório, provocando-nos com o lúcido atrevimento de suas ideias avançadas, rebeldes, mas logicamente muito bem sustentadas e articuladas. Quando ao final ele abriu os debates, indaguei porque ele dava tão pouca atenção a Ferdinand de Saussure e (com ênfase!) nenhuma atenção a Alfred North Whitehead.

Warat respondeu que Saussure já fora suficientemente homenageado e que Whitehead era um autor que não Ihe interessava. Decepcionei-me. Abortei germanicamente um preconceito que estava querendo surgir e procurei guardar os momentos interessantes de sua palestra. Mais adiante, registro, valorizei devida e destacadamente duas de suas obras, "O Direito e sua Linguagem" e "Semiologia e Direito"2. Considero-as muito especialmente como estudos seríssimos, epistemologicamente responsáveis, sendo contributos de alta relevância à Semiologia Jurídica, e com as quais aprendi muito.

O segundo momento ocorreu em início de dezembro de 1983, quando eu recém Doutor pela Universidade de São Paulo - retornei à UFSC e fui recebido pelo Colegiado do Curso de Pós-Graduação em Direito como seu novo integrante, escalado para ministrar as disciplinas Tipos de Estados Modernos e Teoria Política, no Programa de Mestrado em Direito. Fui saudado oficialmente pelo Professor Blasi e, para minha surpresa, Warat pediu a palavra para dar-me boas vindas, enfatizando o que chamou de força renovadora da juventude como elemento chave para o desenvolvimento sempre criativo da pesquisa jurídica.

2 Nas edições argentinas, respectivamente: WARAT, Luis Alberto. El derecho y su linguaje. Buenos Aires: Cooperadora de Derecho e Ciencias Sociales, 1977; e, WARAT, Luis Alberto.

Semiotica y Derecho. Buenos Aires: Eikon, 1972. 
O terceiro momento foi em abril de 1992 quando, sendo eu Coordenador do Curso de Pós-Graduação em Direito da UFSC (então já com os dois Programas consolidados, - Mestrado e Doutorado em Direito), reuni o Colegiado para comunicar que tinha requerido a minha merecida aposentadoria por tempo de serviço, eis que iniciei minhas atividades muito jovem e na condição de arrimo de família.

Muitos dos integrantes do Colegiado se manifestaram e, por último, Warat pediu a palavra para apelar pela minha permanência, ressaltando o que chamou de eficiência na administração dos assuntos organizacionais e científicos do Curso. Fiquei comovido e nos abraçamos fortemente.

Lembrei-me (e disse isto, ali e então, em público) especialmente do período em que, carnavalizando desde a sua vestimenta até e, principalmente, a sua Pesquisa e o seu Ensino, Warat não deixou de ser, num minuto sequer, um Filósofo e um Cientista sério, responsável e efetivamente comprometido com a liberdade de pensar e criar e, ressalto, com a utilidade social da atividade acadêmica.

Recentemente fui indagado sobre se tinha preferência por mais algum dos livros de Warat, além dos dois já citados.

Respondi imediatamente que sim, indicando "A Pureza do Poder"3.

Por quê? Principalmente, a meu juízo e salvo melhor, por sua lógica de conteúdo irrepreensível, e por três momentos de suas Conclusões, nos quais atinge elevado patamar à percepção acurada, séria e responsavelmente crítica, que Warat sempre teve sobre a dinâmica positivista da Teoria Pura do Direito.

Destaco:

(1)"O saber jurídico, enquanto ciência social, deve ser visto como um sistema de articulações tópicas, construídas a partir de problemas e endereçadas à produção de argumentos para a paralização de conflitos sociais"4.

(2) "O conhecimento jurídico deve ser visto mais como uma técnica de efeitos do que uma ciência dos fatos." ${ }^{.}$.

3 WARAT, Luis Alberto. A Pureza do Poder. Florianópolis: Editora da UFSC, 1983.

4 WARAT, Luis Alberto. A Pureza do Poder, p.123.

5 WARAT, Luis Alberto. A Pureza do Poder,p.123 (itálicos no original). 
E, (3) "... o princípio de pureza considera como expressões sem sentido para a Ciência do Direito toda a afirmação que não possa ser derivada de normas jurídicas válidas". ${ }^{6}$

É este Warat que, modesta e convictamente homenageio aqui, e que Luiz Fernando Coelho qualificou, a meu juízo, muito apropriadamente, como um exemplo expressivo de "trabalho intelectual sério e de conteúdo crítico" que produzia permanentes estímulos de "renovação da epistemologia educacional do direito", sempre "compromissado com a realidade do direito e da sociedade."7

\section{REFERÊNCIAS}

COELHO, Luiz Fernando. Apresentação. In: WARAT, Luis Alberto. A Pureza do Poder. Florianópolis: Editora da UFSC, 1983.

WARAT, Luis Alberto. El derecho y su linguaje. Buenos Aires: Cooperadora de Derecho e Ciencias Sociales, 1977.

WARAT,Luis Alberto. Semiotica y Derecho. Buenos Aires: Eikon, 1972.

WARAT, Luis Alberto. A Pureza do Poder. Florianópolis: Editora da UFSC, 1983.

Recebido em: fev/2015

Aprovado: fev/2015 